\title{
INDONESIAN ISLAMISM: \\ THE WAR OF ISLAMIC LITERACY FROM MILLENNIALISM TO RADICALISM
}

\author{
Elia Tambunan
}

Sekolah Tinggi Teologi Salatiga

Sidorejo, Salatiga, Central Java, Indonesia, 50714

E-mail: elia.tambunan@gmail.com

\begin{tabular}{c|c|c}
\hline Received: & Revised: & Approved: \\
15/04/2019 & $06 / 16 / 2019$ & $10 / 06 / 2019$ \\
\hline
\end{tabular}

DOI: http:/ / dx.doi.org/10.32332/akademika.v24i1.1612

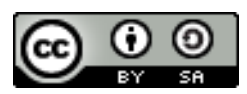

Indonesian Islamism: The War of Islamic Literacy from Millennialism to Radicalism Licensed Under a Creative Commons Attribution-ShareAlike 4.0 International License

\begin{abstract}
This paper shows another dimension of the phenomenon of Islamism Indonesia. By doing the interpretation of a number of circumstantial historical Islam literacy with traces of the historical aspect as the research methodology, the authors found one important factor that gave birth to Islamism Indonesia is literacy not just ideology as believed by many scholars. The resulting literacy evolved in various forms of media, and thus generated by the Indonesia who settled in the Middle East, Islamic Indonesia elite, and ustad virtual at the estuary of the society in the war on Islam. This paper contributes to the efforts of Islamic Studies scholars from Indonesia to include literacy in Islamic Indonesia as part of the phenomenon of global Islamism manifestation in the development of the study of contemporary Islamist movements.
\end{abstract}

Keywords: Indonesian Islamism, Milleniarism, and Radicalism

\section{A. Introduction}

a Many scholars believe in the birth of social movements because of ideology singularly. They believe in ideology as a function too strong. For 
example, Hagopian), Walford refers to the function of 'prescription' philosophical background, pragmatic aspects, and rhetorical functions for the movement. Whereas Scott considers the function of 'grandiose' the main source philosophical system that contains values that guide the existing order. Other scholars such as O'Sullivan, Ayubi, Fuller, Bouyahya also believe that the same function also applies strongly in contemporary Islamic movements in the world and in Indonesia as believed by Yunanto 1 and Machmudi.Not in tune with them, this paper wants to show the birth of Islamic social movements from the other side. One very important driving factor that gave birth to Indonesian Islamism was literacy that was present in the work of Indonesian Ulemas who settled in the Middle East and the Indonesian Islamic elite. Islamism means Islam which is used as a political movement by people, people and groups because of certain situations, conditions and locations ${ }^{2}$

The Indonesian Ulemas not only spread da'wah but also carried out militant transnational literacy wars. Evidently, several prominent Hadrami scholars in the 17th century wrote books to solve religious problems that arose among Indonesian-Malay Muslims. Historical evidence can be seen from the writings of Djajadiningrat.A Head of Qadhi Mecca issued a fatwa to overthrow the King of Aceh because a woman namely Sultanah Kamalat Syah from the Sultanate of Aceh on the grounds that Islam must be ruled by men. With the transnational context, the war was a geopolitical scale. Unfortunately, so far, the strong function and impact of Islamic literacy on birth, the development and evolution of Islamism which will be the main focus of this paper are rarely studied by Islamic studies scholars.

Literacy means, the writings or books of the Ulemas, oral literacy in the form of oral appeals, utterances from mosques or recitations, political ideas or movements in the form of congresses or large meetings that can be carried out when manifesting in the form of an Islamic war. That is to say, a war carried out by Islamist groups which caused a holy war which was aided by the development of Indonesian Islamism was caused by literacy from the Ulemas. Regarding the war on Islam, Snouck ${ }^{3}$ and Jayadiningrat explained, a war that must not stop for the sake of human beings in accordance with the mandate or become Islam. Unbelievers became

$1 \mathrm{~S}$ Yunanto, Militant Islamic Movements in Indonesia and South-East Asia (Jakarta and Singapore: Friedrich-Ebert-Stiftung, 2003), 23.

2 Elia Tambunan, Islamism: One Plot from Egypt, Pakistan and Indonesia (Banten: Arashi Publisher, 2019), 16-25.

${ }^{3}$ C. Snouck Hurgronje, Muhammadanism: Lectures Regarding the Origins of the Development of Religion and Politics, and Their Current ConditionsTranslated by Ruslani (Yogyakarta: IRCSoD, 2019), 95 dan 104. 
converts, and followers of other religious also held Islamic authority. The realization of Islamic ideals so that the world in Muslim authority is one of them through political power.

The Ulemas in general are Hadrami people and their next generation has a privileged position. They oftenly positioned at the highest level of the structure of the Indonesian Islamic community. That happens because they are considered to have higher spiritual degrees, believed to inherit genealogical lines directly from the Prophet Muhammad. Because of this, they received religious respect more than the general public. The call that was given to them was habib or habibah, syarif and syarifah. In general, it is suspected that the Haramais were more instrumental in the formation of post-colonial Indonesian diaspora until now. 4

The Dutch Colonial Government was very familiar with the transnational Islamic geopolitical networks of Mecca and Indonesia, especially those originating from Mecca. Its influence and impact as a rebellion movement against Dutch ambitions to rule Indonesia. Therefore, in the past, as written by Hassan, the Dutch also took advantage of literacy as a tool of war to conquer Indonesian Islam. The literacy war was as part of a strategy to turn off the Islamic movement by the early Indonesian Islamic Ulama as genealogical seeds that drove the Indonesian people to independence. For example, to destroy the Sarekat Islam (SI), the Dutch established a political alliance with an Arab Indonesia from Jatipetamburan, Jakarta to write the book Kafful Awwam 'An Syarikatil Islam. The contents of the book are propaganda to prohibit the general public from entering SI. In 1912, in contrast to challenging the propaganda, Sheikh Ahmad Khatib wrote the book Hassul 'Awwam' Alad Dukhuli fi Syarikatil Islam to mobilize Muslims to enter and support SI so that at a rapid pace, the SI developed rapidly and became the first national political party to reach all Indonesian archipelago. As a further propaganda against Dutch pagan propaganda, Sheikh Ahmad Khatib also wrote the book Assuyufu wal Khanajiru 'Ala Raqabi man Yad'u lil Kafiri, which means anyone's swords and neck beheadings were siding with the Kafir ${ }^{5}$

Thus, in accordance with Suminto for a long time, Islam in the eyes of the Dutch was a political problem. One of the important principles and teachings that became the concern of the Netherlands was the Islamic

${ }^{4}$ Dale F Eickelman dan James Piscatori, "Preface," inDale F. Eickelman, James Piscatori(eds.).Muslim Travellers. Pilgrimage, Migration, and the Religious Imagination. Berkeley, (Los Angeles: University of Califronia Press, 1990), 1-18.

5 "Najwa's Notes with Said Aqil: Said Aqil Regarding Kafir (Part 2), in," youtube, t.t., $24-25$, https://www.youtube.com/watch?v=RTiyIzt7ecA.AccessedMarch, 272019. 
polity known as the Snouck Hurgronje idea. With this political Islam, the Netherlands did not tolerate the entry of political ideas or Islamic fanaticism into the colonies. In this connection, the movements of the ulama and hajj must be arrowed. From a historical perspective, Indonesian Islamism initially focused on the anti-colonalism movement by ulema, hajj, the Indonesian Islamic elite, but in subsequent developments the phenomenon showed a shift towards other phenomena. Unfortunately, not a lot of research has been directed at understanding what factors make Islamism in terms of literacy related to the Indonesian Islamic war. In fact, Noorhaidi stressed one way to read the dynamics and shift of Islamism is to look at the Islamic literature map that forms the fundamental ideology of the Islamic movement that shaped it ${ }^{6}$

\section{B. Method}

Many Islamic historical studies that have enlarged the role of the Middle East not only as a destination for Nusantara Ulama since the 16th century, but also their large contribution in developing a variety of Indonesian Islamic intellectual traditions through a number of works. The Ulemas are still an important reference in the history of the development of Indonesian Islam in various styles. They are believed to have the legality and authority to define Islam in various roles. 7 Some Ulemas are considered to have different ideologies towards the government which are actually eliminated even though they were previously in line so they waged war ${ }^{8}$. Conducted by a literature study of the literacy of the Ulemas which causes and propagates the doctrine of war against legitimate colonialism, the West, even the Indonesian state and against fellow Muslims who are considered 'other' throughout the 15th to 21st centuries, this paper examines Indonesian Islamic literacy from historical prism.

In showing the factors that led to literacy warfare, the authors methodologically approached situational historical interpretation with the intention to focus more on one factor that gave birth to war. A reactive war

${ }^{6}$ Noorhaidi Hasan, "Towards Popular Islamism," in Noorhaidi Hasan (ed.), Islamic Literature of Millennial Generation: Transition, Appropriation, and Contestation. (Yogyakarta: Postgraduate of Sunan Kalijaga State Islamic University Yogyakarta, 2018), 1-27.

7 Jajat Burhanudin, Ulemas and Power: Muslim Political Elite Struggles in Indonesian History (Bandung: Mizan, 2012), 2.

8 Karl D Jackson, Traditional Authority, Islam, and Rebellion: A Study of Indonesian Political Behavior (Berkeley, Los Angeles: University of California Press, 1980), 17. 
based on radical religious values which mobilized Indonesian Muslims into understanding from militarism to radicalism. Meliniarism is the awakening of movements from certain communities which are based on religion, but in the end they are not escaped from the sociological, anthropological and historical side. 9 Whereas, radicalism is an attitude, and the fanaticism of certain people or Muslim groups involved in Islamic activism is at high risk or high cost. 10

Methodological work as described above, if it follows Smelser and Berkhofer, includes behavioral approaches in historical analysis. ${ }^{11}$ The author works in an explanatory and analytical manner but is eclectic by reshowing empirical materials of previous researchers regarding the work of the existing Ulama and seeing them from one particular angle, namely the other effects of the saga. The author makes situational interpretations of the work argumentatively. From the interpretative reconstruction of historical meanings by the author, it is clear that the Islamic literacy movement produced a political movement. Because of the meaning carried out, the work of the ulama resulted not only in changes in political behavior but also in Islamic movements from reactive society. The ulama's work became a literacy war on everything outside of themselves and their own group which was subjectively seen from the perpetrators as corrupting religious values, social structures, economics, politics and culture of traditional societies held previously.

\section{The War of Indonesian Literacy by the Early Ulemas}

For a long time, Islamic literacy became a political force capable of mobilizing the Islamic war over the tyranny of colonialism for centuries. Literacy is more than just the most trusted and organized opposition movement that raises fears of Islamists who gain power in the context of authoritarian countries in the modern world, such as Bubalo, Fealy and Mason. ${ }^{12}$ (A number of literacy scholars who waged the Indonesian Islamic war can be shown here.

9 A. Pieter E Korver, The Samin Movement and Millenarism, ijdragen tot de Taal,Land-en Volkenkunde, Deel 132, 2/3de Afl, 249-266, 1976, 249-66.

10 Radical Islam Rising: Muslim Extremism in the West., vol. Quintan Wiktorowicz (Maryland: Rowman \& Littlefield Publishers, Inc, 2005), 4.

${ }^{11}$ Neil J. Smelser, Theory of Collective Behavior (New York: Free Press, 1962), $13-$ 20; Robert F Berkhofer Jr, A Behavior Approach to Historical Analysis (New York: Free Press, 1969), 33,39-47,118,295.

12 Anthony Bubalo, Greg Fealy, dan Whit Mason, Zealos Democrats: Islamism and Democracy in Egypt, Indonesia and Turkey (New South Wales, Australia: Lowy Institute for International Policy, 2008), i. 
Nur Al-Din Al-Raniri (1068-1658) a Syaikh Al-Islam from 1047-1637 was the highest position in the sultanate of Aceh, namely during the time of Sultan Iskandar Muda alias Iskandar Tsani who died and continued by his wife Sultanah Shafiyyah Al-Din since 1641- 1674. ${ }^{13}$ In his work Bustan Al-Salathin which generally wants to strengthen the power and the Caliphate of God on earth. Non-Islamic groups in particular, such as the VOC, which at that time sent Peter Sourij in 1053-1643 as trade commissioner to Jambi and Aceh who came up with new doctrines, were heretical. Wujudiyah teachings even his own people can be sentenced to death if they do not want to repent. He even issued fatwas to hunt down misguided people, kill people who refused to give up their beliefs and abandon their heretical practices, and burn them to the ashes of all of them ${ }^{14}$ Wujudiyah referred to is Islamic Sufism genre philosophy, which is contained in the Javanese tasawuf written Hamzah Al-Fansuri with his work Sharah al-shiAshiqin. Sufism model developed by al-Fansuri and his student Shamsudiin Al-Sumatrani is an evolution of the teachings of Ibn 'Arabi (d. 1240 AD), Abu Mansur al-Hallaj (d. 922 AD), and other figures.

Previously, Al-Fansuri also wrote Asrar 'Arifin. While Al-Sumatrani produces Jawhar al-Haqa'iq. Their books are the main source of early Sufism in Indonesia. For example, David (1990), Mujiburrahman ${ }^{15}$ and Noor stated that Sufism Islam also developed in the Islamic community of Banjar South Kalimantan or on the island of Java. ${ }^{16}$ But this type of Islam was strongly opposed by subsequent neo-Sufism Sufism figures al-Raniri, 'Abd al-Ra'uf Singkel including Yusuf Al-Maqassari.17 No doubt, this historical fact revealed Raniri was an Acehnese Islamic mujaddid with a radical approach to taking Islamic reform.

13 Azyumardi Azra, "A Hadrami Religious Scholar in Indonesia: Sayyid Uthman," in Ulrike Freitag, William G. Clarence-Smith (eds.). Hadrami Traders, Scholars and Statesmen in the Indian Ocean, 1750s-1960s. (New York: Brill, 1997), 249-63.

14 Azyumardi Azra, Middle East Ulama and Archipelago Islands Network Abda XVII \& XVII: $\quad$ Roots of Indonesian Islamic Renewal Third Printing (Jakarta: Kencana Prenada Media, 2007), 197-228.

15 Mujiburrahman, "Sufism in the Banjar Society: Continuity and Change in Religious Traditions," 2, no. 2 (2013): 153-83; Yusliani Noor, "The History of the Development of Islam in Banjarmasin and the Role of the Banjar Sultanate (XV-XIX Century)" 11, no. 2 (2012): 239-53.

16 Theodore G.Th Pigeud dan Hj. de Graff, Islamic States in Java 1500-1700 (Lieden \&Bandung: The Haque, 1976), 6.

17 Khader Ahmad, "Autoriti Hadith in the Book of Sufism Writing Jawi: One Study of the Book of Hidayah al-Salikin," Journal of al-Qur'an E Hadith AlBayan, 5, no. 10 (2007): 98-99. 
Sheikh Muhammad Yusuf bin Abd Allah Abu Al-Mahasin Al-Taj AlKhalwati Al-Maqassari also known as Tuanta Salamaka from Gowa in South Sulawesi is another very appropriate example of Islamic war literacy. He imitated Muslims in his day because 1683 mobilized Islam as a war movement to fight the VOC-Dutch alliance in Banten after the arrest and exile of Sultan Ageng. At the end of December 1683, Al-Maqassari was exiled by the Dutch to Ceylon, Sri rare. 18 before being exiled further to the Cape of Good Hope, Cape Town, South Africa. ${ }^{19}$ In 1963-1699 while in exile until the end of his life there, even though the VOC made every effort to isolate him as a political prisoner, Al-Maqassari continually wrote war letters to Islam in Banten and South Sulawesi to fight the Dutch 20

More than previously explained, reports W.H. Read, a Dutch Consulate who served in Aceh and became a businessman in a British company from 1819 to 1909 also helped to explain the Islamic literacy war here. He was unable to stem the swift wave of the mail, which came to be known as the will of al-nabi, the Jawi Ulama from Mecca found around 1880 to 1885 had spread to Aceh, Lampung, Banten, Batavia and Priangan. According to Laffan, the contents are a strong indication of the call of Ulemas who live outside Indonesia for Indonesian Muslims to wage an anti-colonialism war and drive away the infidels from Indonesian Islamic land. 21

To recall Hamka's writings, that in terms of the socio-political side of the Minangkabau people in general, the Tuanku are the people who have the highest titles for Alim Ulema or Imam Khatib in West Sumatra. The title intended as the main honor is not only customary but also this religion cannot be inherited.22 Thus, with the viewpoint of Islam in Sumatra, Java and Sulawesi, it can be understood as to how strong and militant the Indonesian Islamic community practices the war literacy of Sheikh Ahmad Khatib whose values can be equated with practicing Islamic Shari'a.

18 Yusuf Da Costa, Pages from Cape Muslim History. Pietermaritzburg, (South Africa: Shuter \& Shooter, 1994), 19; William Cummings, A Chain of Kings: The Makassarese Chronicles of Gowa and Talloq (Leiden: KITLV Press, 2007).

19 Ebrahim Ahomed Mahida 1993, History of Muslims in South Africa: A Chronology (Durban: Arabic Study Circle, Mahida), 3,4,33.

${ }^{20}$ Mansoor Jaffer, "Guide to the Kramats of the Western Cape," 1996; Kerry Ward, Networks of Empire: Forced Migration in the Dutch East India Company (Cambridge, UK and New York: Cambridge University Press, 2009), 232-33.

${ }^{21}$ Michael Francis Laffan, Islamic Nationhood and Colonial Indonesia: The Umma Below the Winds (London and New York: Routledge, 2003), 39-41.

${ }^{22}$ Hamka, My father: Curriculum vitae H. Abd Karim Amrullah and the Struggle of Religion in Sumatra (Jakarta: Djajamurni, 1967), 24. 
Moreover, in Islam it is generally known, by legal experts and Indonesian Islamic law, adat has an important position in legal construction in general as well as Islamic jurisprudence so that it is often used as legal grounds for religious political interests in conservatism. And, the Sheikhs have a special position as sources of legal law and are principled to deal with and interpret new situations. ${ }^{23}$

A number of Indonesian Ulemas, although living, learned to teach Islam in the Hijaz region, but the ideas of their political Islam intersected strongly at the height of colonialism in Indonesia. That is, the Indonesian literacy war must be positioned as a reaction to the reality of oppressed Indonesian Islam. The war of literacy is closely related to the geo-political dynamics of Middle Eastern Islamism, especially Mecca. Bruinessen said that there were three Indonesian Ulemas who taught at the Al-Haram Mosque which had a big influence among the Nusantara people, Nawawi Banten, Ahmad Khatib, and Kyai Mahfuzh Termas. After the three Ulemas there were no Indonesians who were equivalent to those who taught in Mecca. Their writings influence the generation of followers, especially Indonesian pilgrims.

The Indonesian pilgrims who lived for years in Mecca were known as Mukimin. According to Abdurrahman Wahid, they are also referred to as the Jawi Ulemas who have absorbed the traditions of the Middle East region, to become the standard for their native land in the archipelago. Big names like Syekh Arsyad Banjar, Syekh Abdul Karim Banten, Syekh Abd Al-Muhyi Pamijahan in Tasikmalaya, Syekh Mahfuzh Termas in Pacitan, Syekh Khalil Bangkalan, Syekh Hasyim Asy'ari Tebuireng in Jombang are the main representatives of the Kurdish tradition in the archipelago, or the creators of Islamic literacy known as the Kitab Kuning Pesantren from the work of the Jawi Ulemas. ${ }^{24}$ They are very active in deepening religion.

${ }^{23}$ MB. Hooker, Adat Law in Modern Indonesia (Oxford, UK: Oxford University Press,1978., 1973), 33; Daniel S Lev, Islamic Courts in Indonesia: A Study in the Political Bases of Legal Institutions. (Berkeley and Los Angeles, CA: University of California Press, 1972), 31; Taufik Adnan Amal dan Samsu Rizal Panggabean, Politics of Islamic Law: from Indonesia to Nigeria (Jakarta: Pustaka Alvabeta, 2004), 111.

${ }^{24}$ Abdurrahman . dan Wahid, "Foreword", in Martin van Bruinessen, Yellow Book, Islamic Boarding School, and Tarekat: Islamic Traditions in Indonesia (Jakarta: Mizan, 1995), 13. 
Mukimin, also often called the Javanese colony, is a "reservoir for Islam in Indonesia." 25

The Mukimin, especially from Java or even Sumatra, is a group of 'Kauman' as the heart that pumps the Indonesian literacy incessantly. They consist of professors who are highly respected by the Indonesian people, including Mecca itself. The Mukimin are very fluent in the Islamic literacy war movement. Roff's research shows that the Mukimin constantly indoctrinated the religion they studied including the political situation at that time, especially to the pilgrims of their respective villages. The Kauman were advisors to the villagers and also as writers of religious works in Arabic and Malay, many of which were sent to Indonesia. They became a permanent source of Islamic thought in Indonesia (1970: 172).

Indonesian Ulama in the Middle East are travelers because they often commute between Indonesia and Hijaz in order to fulfill invitations to offer recitations in mosques, sell books and prayer beads, gather pilgrims to accelerate the pace of the Indonesian Islamic literacy war. They continually instill influence in religious life for the people of the village so that after returning to the hajj the village flock becomes a key cleric in religious life while establishing a correspondent for the maintenance of the transnational Islamic geopolitical network of Mecca and Indonesia. ${ }^{26}$ Upon the return of a number of Indonesian students from Sheikh Ahmad Khatib who learned directly from him at the Grand Mosque, they inflated the ideology of soulless Islamism and aimed at Indonesian independence from the Netherlands. For example Kyai Haji Ahmad Dahlan founded the Islamic movement in Yogyakarta namely Muhammadiyah, and Dr. Abdulkarim Amrullah Buya Hamka's biological father founded the Thawalib Islamic movement in West Sumatra ${ }^{27}$

The geopolitical network of transnational Islam, as explained above, also influences their religious perceptions of Islam, the homeland and other religions in Indonesia, including the success of arousing Islamic political fanaticism towards colonialism. April 1, 1911, in Minangkabau, Al-Munir magazine published by Haji Abdullah Ahmad a student from Sheikh Muhammad Thaher Djalaluddin Al Azhari in 1909 had previously published the magazine Al-Imam in Singapore who had also read the

${ }^{25}$ Harry J Benda, "South East Asian Islam in the Twentieth Century," in M. Holt, Awn KS Lambron, Bernard Lewis (eds.). The Cambridge History of Islam (New York: Cambridge University Press, 1970), 182.

${ }^{26}$ B Schrieke, Indonesian Sociological Studies II. (Bandung: The Hague, 1957), 248.

${ }_{27}$ M. Zein Hassan, Indonesian Revolution Diplomacy Abroad (Jakarta: Bulan Bintang, 1980), 24. 
writings of Islamic reformers in Al-magazine Manar when Sheikh Muhammad Thaher studied at Al Azhar University in Cairo. (Dervish, 2013: 78-80). The publication of the magazine as a mouthpiece of Indonesian Islamic literacy was inseparable from the influence of Jamaluddin Al-Afghani along with Muhammad Abduh who published the magazine Al Urwatul Wutsqa in Paris in 1884. Through the Islamic magazine, both made the Islamic world come back to Islam as a way of life in everything including to liberate his country from the tyranny of pagan nations ${ }^{28}$ The Ulemasand Hajj as well as playing an important role as a literacy war infrastructure. From the 17th to 20th centuries the Middle East Ulama network with the Archipelago was very effective as the root of Indonesian Islamic reform, ${ }^{29}$ when Islamic revivalism was raging, as also emphasized by Imdadun, also connected to Indonesia. ${ }^{30}$

In addition to those described above, Shaykh Abdus-Samad AlPalimbani from Palembang with his book saw al-Muslimin wa Tadzkiratu al-Mu'minin fi Fadlail al-Jihad fi Sabilillah wa Karamati al-Mujahidin fi Sabilillah also became a reference for the Aceh mujahid in mobilizing stable war against Dutch colonialists. With the expertise of the literacy war, he also wrote to the kings of the Archipelago to wage jihad fi sabilillah against invaders. ${ }^{31}$ Through this work, he stressed that jihad fi sabilillah with the arguments of the Qur'an and Sunnah is an obligation for every Muslim. They must fight infidels or infidels if they enter with the intention to colonize their territory. This became the main grip of the Acehnese when fighting the Netherlands. He also sent two letters to the Sultan of Mataram Hamengkubuwana and Susuhunan Prabu Jaka, meaning the son of Amangkurat IV, as a call for jihad fi sabilillah over the invaders. ${ }^{32}$ This shows how in the era of war against the Netherlands, the early Indonesian Ulama, as seen from Aceh appeared as a hero who used literacy of jihad as

28 Jamaluddin Al-Afghani dan Muhammad Abduh, Ta'assubTranslated by Abdullah Basmih (Singapore: Ta'assub, 1950).

${ }^{29}$ Azyumardi Azra, The Origins of Islamic Reformism in Southeast Asia: Networks of Malay- Indonesian and Middle Eastern "Ulama" in the Seventeenth and Eighteenth Centuries (New South Wales: Allen \& Unwin., 2004).

${ }^{30}$ Imdadun Rahmat, New Flow of Radical Islam: Transmission of Middle Eastern Islamic Revivalism to Indonesia (Jakarta: Erlangga, 2005).

${ }^{31}$ Mal An Abdullah, Shaykh Abdus-Samad al-Palimbani: Biography and Scientific Heritage (Yogyakarta: Pustaka Pesantren, 2015).

32 Dzulkifli Hadi Imawan, The Intellectual Network of Shaykh Abdusshamad AlFalimbani and His Contribution in Grounding Islam in Indonesian Archipelago at 18th Century AD, Millah: Jurnal Studi Agama, Vol. 18, No. 1, 31-50, 2018, 3150 . 
a form of war in the way of Allah. In fact, according to Hasan, Ulemas from Palembang, Al-Palimbani and Al-Banjari from South Kalimantan also called for a religious war against anyone who was not his group through the famous Tuhfat al-Raghibin book. Al-Palimbani, as well as Sheikh Muhammad Arsyad Al-Banjari, which will be explained below, as early Indonesian scholars with their very authoritative works in the development of Islamic discourse in the archipelago. ${ }^{33}$

Sheikh Muhammad Arsyad Al-Banjari with the title Tuan Guru reflected the role of the Banjar cleric who became an influential figure in the palace ring. ${ }^{34}$ However, he gained cross-national geo-political legitimacy because he studied with Sheikh Abd Al-Rahman Al-Mubin Al-Fattani, a Southeast Asian Ulema who settled in Haramayn. ${ }^{35}$ It is known that in the 17 th to the 19th century the role of the ulama was very strong, the guardian was not only the spreader of Islam but also functioned as a supporter of the legitimacy of the king's power. This legitimacy is carried out through genealogical signals as well as the descent continuity that is needed. ${ }^{36}$

Al-Banjari lived in the range from 1712 to 1810 known as the Shafi'i fiqh cleric who mastered the problem of Sufism, and his thoughts could put shariah teachings as the basis of Sufism. ${ }^{37}$ The differentiator of the Kingdom of Banjar with other kingdoms in Nusantara is the musyawarah organization, "Crown Council." Its members consist of 'bubuhan', meaning the king's relatives, the royal family group. This institution, emerged since the 17th century in the Banjar Sultanate, chaired by Mangkubumi. This official knows political, economic and socio-cultural issues. They can influence the Sultan and in certain situations can seize the position of the

33 Wan Mohd Shagir Abdullah, Sheikh Muhammad Arsyad al-Banjari Author Sabil al- Muhtadin (Kuala Lumpur: Khazanah Fathaniyah, 1990), 67-85.

34 Syekh Muhammmad Arsyad Zamzam dan Jusuf Halidi, ..Kalimantan Great Ulama: Sech Muhammad Arsyad al-Banjari (Martapura: Yayasan al-Banjari, 1968); Tamar Djaja, Sjech M. Arsyad al Banjari in the Indonesian Library (Djakarta: Bulan Bintang, 1965); Shagir Abdullah, Syekh Muh. Arsyad alBanjari, The Islamic Sun (Pontianak: al Fathanah, 1983); Abu Daudi, Maulana Sekh Moh. Arsyad al Banjari Pioneer of Islamic Da'wah in South Kalimantan, vol. 6 (Mimbar Ulama, 1976), 69-82.

${ }^{35}$ Wan Mohd Shagir Abdullah, Sheikh Muhammad Arsyad al-Banjari Author Sabil al-Muhtadin, 24.

${ }^{36}$ Hasan Muarif Ambary, Historical Dynamics and Socialization of Islam in Southeast Asia 11th-17th Century AD (Jakarta: Depdikbud (Indonesian Ministry of Education and Culture, 1997), 32-33.

37 Syukur, M. Asywadie (ed.). 2003. Sheikh Muhammad Arsyad al-Banjari: Kitab Sabil al-Muhtadin. Surabaya: Bina Ilmu, t.t., xx. 
Sultan. The Mahkota Council is chaired by Mangkubumi with four deputies, Pangiwa, Food, Gampir, and panumping. The existence of the Crown Council depends on the policies of the Sultan who was in power at that time. Al-Banjari is included in the Crown Council. He was the adopted son of Sultan Hamidullah or adopted brother of the Prince. ${ }^{38}$

Al-Banjari in the book Sabil al-Muhtadin is the Islamic reference of Borneo in matters that are closely related to shariah and very serious Islamic law there. While Tuhfat al-Raghibin as an argument reinforces the opinion of the faith, explains the errors in some firqah in Islam, and updates on the traditions of local communities. ${ }^{39}$ That is to say, Al-Banjari and his works are the early scholars who became genealogical roots and the main reference for Banjarmasin intellectuals and Islamic society which are recognized in historical trajectories. ${ }^{40} \mathrm{He}$ is the strongest anchor in terms of good studies, the Hadith of Islamic Ulama, Banjar and even Indonesia. In the oral tradition of the Banjar community, there is a Sufi figure known as Abdul Hamid Abulung. Abulung from Yemen is a Sufi figure who teaches philosophical Sufism the same fate as Al-Hallaj who was executed because of his pantheistic ideology which is considered heretical and misleading. With these heretical charges, he was executed by the kingdom based on a fatwa written in the book Tuhfat al-Raghibin, namely "there is no doubt that he must kill him because of his apostasy. And killing like that person is better than killing a hundred legitimate infidels, "issued by Al-Banjari.41 Because Abulung teachings troubled the community he was sentenced to death at the age of 55 years at the behest of Sultan Tahmidullah II (17851808) in the Kingdom of Banjar Martapura.

Al-Banjari has an important influence on the political struggle of the Banjar kingdom, the system of government by giving birth to Kingdom laws based on Islamic law. He has full authority to determine the lines of

38 J.J. Ras, Hikayat Banjar: A Study in Malay Historiography (Martinus Nijhoff: The Hague, 1968), 233; Dan Idwar Shaleh, Papper Trade and the Rulling Class of Banjarmasin in the Seventeenth Century (Leiden: Ducth-Indonesian Historical Conference., 1978); Milner AC, "Islam and The Muslim State," dalam M.B. Hooker (ed.), Islam in South Easth Asia (Leiden: Brill, 1988), 23-49.

39 Abdul Majid, "Critical Study of Sabil al-Muhtadin's Hadiths" (Thesis, Postgraduate School Syarif Hidayatullah State Islamic University Jakarta, 2007), 67.

40 Husaini Abbas Rahmadi2012., Islamic Banjar: Genealogy and Intellectual References in Historical Trajectories (Banjarmasin: The State Islamic Institute of Antasari Press, 2012), 9-10.

${ }^{41}$ Hanafi, "Genealogy of the Study of Hadith of Ulema al-Banjari" 2, no. 2 (2017): 169-94. 
political policy and use political instruments to implement the Sultan's policies. ${ }^{42}$ It's not that simple. Also, Al-Banjari as an early Indonesian scholar with a very authoritative book not only in the development of Islamic literacy in the archipelago but its impact was also able to wage a religious war against anyone who was anti-Islamic in particular. ${ }^{43}$

Not only until the previous explanation. In the history of Indonesia, the rebellion against the Indonesian Government after 1945 was also mobilized by Ulemas. That can be seen as the case of DI / TII in the 1950s. All activities of the Ulemas were concentrated from dayah-dayah in all parts of Aceh not from the Islamic royal palace. In Aceh, Bustaman-Ahmad called the Ulemas known as teungku, abu, abi, waled, abati, and abon as a form of the hierarchy of the Acehnese people to control the religious lifestyle of the community.

Another Acehnese Ulema who is respected by the community is Teungku Muhammad Daud Beureueh. He achieved considerable popularity as one of the Ulemas in Aceh. In his hours of lectures at the mosque he was able to enchant people, condemned Acehnese who abandoned Islamic faith and interpreted unlawful and unbelievable things to people who were not liked when the sermon at the mosque, in meetings and wherever it was deemed necessary. He is the Chair of the All Aceh Ulemas Association (PUSA). PUSA was as a religious, sociopolitical organization to respond to the rules for the banning of the establishment of Islamic political organizations by the Dutch. This raised the Islamic fanaticism of the Ulemas in Aceh. Through PUSA they beat the war of struggle against Dutch oppression. At the initiative of several scholars led by Teungku Abdurrahman a PUSA was formed in Matang Glumpang Dua, Pidie District. In his formation congress, Daud Beureueh was elected chairman. In April 1951 and September 1953 at the I and II Aceh Ulemas Congress in Medan he still had an important position there. Previously, on October 15, 1945, he and on behalf of the Aceh Ulemas and the Ulebalangs declared the Sabil War as the holy war of Islam. Also on behalf of the Aceh Ulemas, the rebels spread a number of pamphlets throughout Aceh with

42 Ahmad Suriadi, Sheikh Muhammad Arsyad Al-Banjari in the Political Dynamics of the XIX Century Banjar Kingdom (Banjarmasin: Research Center and publishing LP2M Antasari State Islamic Institute, 2014), 1-56.

43 Noorhadi Hasan, Laskar Jihad: Islam, Militancy, and the Search for Identity in Post-New Order Indonesia Translated by Hairus Salim (Jakarta: LP3ES associate with KITLV Jakarta, 2008), 67-85. 
the aim of mobilizing the Acehnese against the Dutch and also rebelling against President Sukarno. ${ }^{44}$

In a further development, Daud Beureueh felt betrayed by Sukarno and the circulation of hoaxes from the Sukarno circle about the plan to assassinate 300 Acehnese Ulemas. This situation, according to Dewanto, caused Daud Beureueh to declare war so that it was considered the Acehnese Islamic separatism movement over Jakarta. Because he was not willing to be included as part of the Province of East Sumatra which tended to be controlled by the Christian Batak, then as a rebellion against the Sukarno Government, he proclaimed the Darul Islam and the Indonesian Islamic State (NII) in Aceh. NII Aceh is part of Kartosuwiryo in West Java. ${ }^{45}$ Beureueh continued to surround almost the entire Aceh region while giving provocative lectures in support of the idea of an Islamic State. ${ }^{46} \mathrm{He}$ sentenced the Javanese and Medan people as infidels. For him Sukarno was the president who only promoted Hinduism and was anti-Islam. ${ }^{47}$

In the ideas of separatism, Compton stated that Beureueh also wanted an Islamic State for all of Indonesia, and not only for free Aceh. He longed for the reign of Sultan Iskandar Muda, Aceh to become an Islamic State of one State of Aceh-Indonesian Islamic State (NBA-NII) (1993). He continued to fight until 1964 before then later paralyzed and died in 1987 by the New Order Government systematically. ${ }^{48}$ This explanation would emphasize that the Aceh war was a fanatical Islamic movement to show Islamism against colonialism. It was also a reaction or logical consequence of the Ulemas and Ulebalangs who rejected centralistic integration in the Indonesian state which only benefited Jakarta as the center of government but tormented the Acehnese people in the region. ${ }^{49}$ Centralistic integration

${ }^{44}$ B.J Boland, The Struggle of Islam in Modern Indonesia (The Hague: Martinus Nijhoff, 1971), 68-75.

${ }^{45}$ Anthony Reid, An Indonesian Frontier: Acehnese and Other Histories of Sumatra (Singapore: NUS Publishing, 2005), 19,424.

${ }_{46}$ C. Van Dijk, Rebellion Under the Banner of Islam: The Darul Islam in Indonesia. (The Hague: Martinus Nijhoff Publishers, 1981), 300-330.

${ }^{47}$ Keat Gin Ooi (ed.), Southeast Asia: A Historical Encyclopedia, from Angkor Wat to East Timor (Santa Barbara, California: ABC Cilio, 2004), 402.

${ }^{48}$ R. William Liddle, New Order Elections: Tidal Political Power (Jakarta: LP3ES, 1995), 90-110.

${ }^{49}$ Jaqueline Aquino Siapno, Gender, Islam, Nationalism and the State in Aceh: The Paradox of Power, Co-Optation and Resistance (London: RoutledgeCurzon, 2002), 122. 
actually removes social traditions and changes the power of Ulama in Aceh's political leadership. ${ }^{50}$

The historical facts of other Islamic literacy wars can also be seen from Banten. Banten's Islamic literacy wants to show that the Ulemas and Hajj, who were the key caretakers of the Indonesian Islamic community from the beginning, were not just leaders of the resistance movement against the Dutch. However, they were also interpreted by the people as leaders of the religious Messianic movement in the concepts of Imam Mahdi and Ratu Adil the savior of Java. ${ }^{51}$ The bad impact of Islamic lietration, July 9-13, 1888, was experienced by the Dutch in the events of the movement of farmers in Anyer, Banten. ${ }^{52}$ In the Banten war, the role of Syaikh Nawawi al-Bantani from Banten could not be decided from the sparks of Islamic thought as a political movement from the ulamas on a hybrid basis. Because of political thought and also for political reasons, the Dutch sent espionage to oversee al-Bantani's movements. ${ }^{53}$

The previous explanation is to show the historical fact of the Indonesian Islamic literacy war that was mobilized across the country massively by the Hadrami Ulama. However, by the majority of Hadrami scholars in the archipelago, mobilizing the Islamic literacy war was also motivated by personal economic interests and contestation of influence between fellow Ulama Hadrami. For example in 1822-1913 Al-Habib Sayyid 'Uthman bin Abd Allah bin Aqil bin Yahya Al-Alawi Al-Husaini while spreading Islamic values also mobilized the economic distribution of Islam in Betawi. ${ }^{4}$ Even though at that time, he was an 'insider' from Colonial Government. He works as an honorary employee (adviseur honorair) in the administration of the Dutch East Indies for Arab Islamic affairs from 1899-1914 in Het Kantoor voor Islamtische en Arabische Zaken.

50 TIim Kell, The Roots of Acehnese Rebellion, 1989-1992 (Itacha: Cornell SEAP Publication, 1995), 1.

51 Sartono Kartodirdjo, Protest Movements in Rural Java: A Study of Agrarian Unrest in the Nineteenth and Early Twentieth Centuries (New York: Oxford University Press, 1973), 64, 103.

52 Sartono Kartodirdjo, The Peasants' Revolt of Banten in 1888: Its Conditions, Course and Sequel: A Case Study of Social Movements in Indonesia. echt. (Netherlands: Springer Science+Business Media Dordr, 1966), 1.

53 Samsul Munir Amin, Percik the Thought of the Kiai (Yogyakarta: Pustaka Pesantren, 2009), 2.

${ }^{54}$ Azyumardi Azra, "Hadhrami Scholars in the Malay-Indonesian Diaspora: A Preliminary Study of Sayyid Uthman" 2, no. 2 (1995): 1-33. 
He is a close friend of Snouck Hurgronje, L.W.C. Van den Berg and K.F. Holle. ${ }^{55}$

Habib Sayyid 'Uthman was born in Pekojan, Betawi, Batavia on December 1, 1822. In addition to studying in Makkah and Hadramaut, he studied in Egypt, Tunis, Algeria, Jordan and Turkey. Because of the modern culture in the country he visits, he is dressed in a modern manner in his association. Because of his extensive knowledge, by the Dutch East Indies government, he was appointed as the Betawi Mufti as well as being used as a tool for literacy warfare.In his work 'Minhaj al Istiwamah fi alDin al-Salamah' written in 1889-1890 discusses jihad. He explained the jihad in Banten that appeared in 1888 because the people there misunderstood the teachings of Islam. He said the jihad was only a security disturbance that would bring misery to Muslims. He called the jihadists shaitan because jihadists have ignored the teachings of Islam. He felt the need to help the Dutch in matters of political Islam (Algadri, 1994). 'Uthman, under the pretext of the desire for peace in the Dutch East Indies and upholding the law for security, opposed other Ulemas, especially those who were less friendly to him. He strongly criticized Shaykh Ismail alMinangkabawi and Shaykh Sulaiman al-Affandi who introduced the Naqshbandiyah tariqat in Minangkabau. According to 'Uthman, this tarekat has brought about the destruction of Muslims. He was also involved in a polemic with Shaykh Ahmad Khatib al-Minangkabawi who was a prominent figure in the Wahabi movement in the Minang realm and considered the movement to be very radical whose influence was bad for Indonesian Islam. That is the reason, 'Uthman, argues that the Wahhabis are the most lying Muslim group. ${ }^{56}$

\section{The War of Indonesian Literacy by the Islamic Elites}

The war of Islamic literacy over colonialism is increasingly blatantly developing in the body of the Sarekat Islam (SI). It started from Tjokroaminoto, Agus Salim, Natsir, and then it was increasingly formed in the form of separatism. The separatist movement was carried out by Kartosuwiryo, Abdullah Sungkar, Abu Bakar and his successors until after reformation in Indonesia. It has become a common understanding that $\mathrm{SI}$ is not only one womb that gave birth to the elite of modern Indonesian Islam

55 Abigail Green dan Vincent Viaene (eds), Religious Internationals in the Modern World: Globalization and Faith Communities Since 1750 (New York: Palgrave Macmillan, 2012), 204.

56 Ahmed Ibrahim Abushouk dan Hassan AhmedIbrahim, The Hadhrami Diaspora in Southeast Asia: Identity Maintenance Or Assimilation? (Leiden: Brill, 2009), 43. 
as Niel found 57 but in accordance with Elson also became a modern Indonesian Islamic organization that conceptualized the idea of a new modern Indonesia. ${ }^{58}$ But in its development, SI can also be seen as part of the development of the Indonesian Islamic literacy war. SI as a radicalist movement presupposes that SI is a political movement of Javanese society. As a political movement, SI overflowed into most parts of Indonesia. SI articulates state and nation consciousness in a fanatic yet popular modern format. ${ }^{59}$

SI relies on Islam as a principle of ideology. But, that ideology must be incorporated into its context as a driving force for the struggle for independence and attitudes towards injustice to the suffering of Indonesian people. ${ }^{60} \mathrm{SI}$ as a power of political Islam which is a representation of mass Islamic organizations, was originally intended to advance the economy of Muslims, but was so quickly involved in issues and practical political actions. ${ }^{61}$ That is because the SI from 1924 to 1927 was very intensive talking about the problem of Islam. The plan for the SI work in those years outlined that all existing regulations were based on Islam. In its role as an Islamic organization, SI was directed by Hadji Oemar Said (H.O.S.) Tjokroaminoto to programs to make Islam an alternative to capitalism and communism. That direction was expressed in Islamic Socialism. ${ }^{62}$ In the ideals of SI Tjokroaminoto there was an Islamic mileniaris movement. Where, at the height of its popularity, it was perceived by the Javanese people as the Messiah from the land of Java and the real manifestation of the Fair Queen in Javanese Islamic myths such as preserving the

57 Robert Van Niel, The Emergence of the Modern Indonesian Elite (Bandung: W. Van Hoeve, 1960), 96,126,157.

58 R.E.Elson, The Idea of Indonesia: A History. (Cambridge, UK: Cambridge University Press, 2008), 13,75.

59 Takashi Shiraishi, An Age in Motion: Popular Radicalism in Java, 1912-1926. (Itacha: Cornell University Press, 1990), 82.

60 Amelz, H.O.S. Tjokroaminoto: His Life and Struggle (jakarta: Bulan Bintang, 1952), 4 .

61 Azyumardi Azra, "Preface: The Dynamics of PSII The Political Prism of Indonesian Islam," inValina Singka Subekti. Indonesian Islamic Party (Jakarta: Yayasan Pustaka Obor Indonesia, 2014), ix.

62 Burhan Djabir Magenda, "Foreword,"in Valina Singka Subekti, Indonesian Islamic Sarikat Party: Political Contestation to Elite Power Conflict (Jakarta: Yayasan Pustaka Obor Indonesia, 2014), xxi. 
predictions of Jayabaya. He is titled Prabu Heru-Tjokro, a name that is exactly the same as Tjokroaminoto. ${ }^{63}$

The Javanese Islamic mileniaris movement also appeared in Prince Diponegoro. He has the Islamic name Sultan Abdul Hamid Herucakra Kabirul Mukminin Sayidi Panatagama Kalifatul Rasul Tanah Jawa. He also declared himself as Queen of Justice by bearing the title of Sultan Erucokro. The title was used to mobilize radicalism in Javanese society against the Dutch during the Java war. ${ }^{64}$ Indeed, the militarization of the Javanese war which was driven by factors of economic colonization lasted from 1825 to 1830. The war succeeded in mobilizing at least 2000,000 Javanese people from Batavia, Central Java, East Java and many areas in the northern coast to fight the Dutch colonial government for the first time. It is the biggest war on the island of Java. The war involved the myth of Javanism and Islam or the Sabil War versus the Crusades. In fact, it is an Islamic Islamization that is linked to pumping the spirit of Javanese martyrs for independence despite having to swallow at least 200,000 victims. At least 8000 Dutch soldiers and 7,000 Indonesian soldiers were killed in the war. ${ }^{65}$

The phenomenon of the movement of the Tjokroaminoto mileniaris was evident when he added the name of Islam to himself to be Hadji Oemar Said. It was done after he performed the Haij in $1926 .{ }^{66}$ In the unity of the Javanese Myth and Islam, he was able to mobilize the political movements of the Javanese people in Surabaya in one movement Djawa Dwipa. The movement was commanded by Tirtodanoedjo and Tjokrosoedarmo. In that movement, Tjokroaminoto changed high Javanese language, chromo, into everyday language which Javanese perceived as low, ngoko. In 1916-1917, he mobilized the Kandjeng Prophet Muhammad's Army to defend Islam. He also established an alliance with

${ }^{63}$ A.Pieter E. Korver, Sarekat Islam: Ratu Adil Movement? (Jakarta: Grafitipers, 1985), 30,52,77.

64 Peter B.R.Carey, Destiny: The Life of Prince Diponegoro of Yogyakarta, 17851855 (London: Peter Lang, 2014), 251; Peter B.R. Carey, The Power of Prophecy: Prince Dipanagara and the End of an Old Order in Java, 1785-1855 (Leiden: KITLV Press, 2007), 585.

65 Peter B.R. Carey, "The Cultural Ecology of Early Nineteenth Century Java: Pangeran Dipanagara," A Case Study, Occasional Paper (The Institute of Southeast Asian Studies, 1974), 4; Merle Calvin Ricklefs, Mystic Synthesis in Java: A History of Islamization from the Fourteenth to the Early Nineteenth Centuries (EastBridge Books, t.t.), 204.

${ }^{66}$ Harsono Tjokroaminoto, Following in the Footsteps of the Father's Struggle (Jakarta: Gunung Agung, 1985), 1; The Old Soerabaia Volume 1 (Surabaya: Surabaya Tourism Departement, 2002), 147. 
Arab descendants to fight other Islamic movements patterned in the Semaoen version of SI Semarang. ${ }^{67}$ Tjokroaminoto wants the Javanese and Indonesian people in particular to unite because of their shared sense of belonging and a determination to demand independence. ${ }^{68}$ Although he was a raden, as a clerk on Patih, he worked for a Dutch company. He abandoned divine feudalism by removing all the attributes associated with it. He protested the behavior of dodok which was walking squat and kept bowing in front of the nobility. He actually called on his followers to wear European clothing as a movement for the equality of the Javanese people, Indonesia with the Dutch people. ${ }^{69}$

SI must be seen in the frame of the history of the Indonesian people's national movement for independence under the banner of Islam so that people live according to religious orders rather than others. SI emerged so that the public eliminated erroneous notions about Islam. He was also a trade cooperative movement to challenge the dominance of the Chinese economy, Christianization and the Javanese cultural heritage. ${ }^{70} \mathrm{SI}$, known as Tiga Serangkai, namely Tjokroaminoto, Salim and Abdul Muis directed the resistance of the Javanese community to communism. As is known, at that time the ideology of the PSII party was formed by Semaun, Darsono, Malacca was a pattern of Marxism. They want religion to be removed from practical politics. All party activism is carried out on the principles of Marxism. ${ }^{71}$ This explanation would emphasize that Agus Salim placed himself as a leader during the formation of SI political ideas in the thick color of Islamism.

In 1915, since Agus Salim joined SI, he became the second leader after Tjokroaminoto. Salim strives to advance, organize, organize the life of the ummah in the aspects of economic, social, cultural based on Islam. He defended SI from the penetration of the influence of the red communists led by Semaoen, Darsono, Tan Malaka and Alimin Prawirodirdjo. Salim uses Islam as an ideology of struggle in all national life. ${ }^{72}$ However, Salim

67 Onghokham, Sukarno: Left Man, Revolution E G30S 1965 (Jakarta: Komunitas Bambu, 2009), 5.

68 Amelz, H.O.S. Tjokroaminoto: His Life and Struggle, 86-87.

69 Budi Setyraso dkk (eds.), Tjokroaminoto The Founding Teacher Sixth Printing (Jakarta: KPG, 2018), 2.

70 A.K. Pringgodigdo, Movement History of the Indonesian People Tenth Printing (Jakarta: Dian Rakyat, 1984), 4-5.

71 Fauzi, Islamists vs. Secularists: Idiological Fighting in Indonesia (Semarang: Walisongo Press, 2009), 45.

72 Suradi, Haji Agus Salim and Political Conflict in Sarekat Islam (Jakarta: Pustaka Sinar Harapan, 1997), 29. 
was in a political movement that favored the openness and availability of cooperating with anyone who was in the same direction and moved politics in a parliamentary manner ${ }^{73}$

Agus Salim's enthusiasm was the crystallization of Islamic knowledge he had obtained from previous Islamists, for example Sheikh Ahmad Khatib and Muhammad Abduh. In accordance with Rahmat Baniam's research, Salim also studied with Sheikh Ahmad Khatib the High Priest of the Grand Mosque. He also explores the teachings of Muslim reformers such as Jamaluddin Al-Afgani and Muhammad Abduh. ${ }^{74}$ Sheikh Ahmad Khatib was uncle of Agus Salim. In 1906-1911, when Salim worked at the Dutch Consulate in Jeddah, he studied with his uncle ${ }^{75}$. At that time Abduh's thinking from Egypt teaching Islamists was not confined to a particular school of Islamic thought that was sticking out so much that it influenced ulama from Minangkabau. ${ }^{76}$ With the accumulation of teachings from the Islamic reformers, Salim called for the return of hijrah politics.

The politics of migration is a strategy against the Dutch colonial government. It was as a result of the new direction of the Dutch Indies Islamic politics. The emergence of new ideologies in SI, and the arrest of SI leaders, namely H.O.S. Tjokroaminoto ${ }^{77}$ also influenced the direction of the SI Islamist movement. The main purpose of the hijrah politics is to establish a state based on Islamic law. The emergence of a new ideology in the SI which was initiated by Salim produced a migration brochure. The brochure is used as a guide for stepping and moving. The initial intention of the hijrah politics was intended to break away from all forms of influence and systems of life and the Colonial Government and begin to form Islamic state forms of all aspects of life, both social, economic and political based on the potential and strength of the Islamic Shari'a. The PSII National Congress in Madiun on 17-20 February 1923 discussed the party's political

73 Mas'oed Abidin, "Minangkabau Encyclopedia.Minangkabau:" (Minangkabau: Center for Islamic Studies, 2005), 44.

74 Rahma Baniamt, "Political Gait Haji Agus Salim in Sarekat Islam (1915-1940 AD)," (Thesis, Department of Islamic History and Culture Faculty of Adab and Cultural Sciences Sunan Kalijaga State Islamic University Yogyakarta, 2017), vii.

75 Arif Zulkifli, et.all (eds.), Agus Salim Joker Diplomat and the Pole of Republic (Jakarta: KPG. "2018 PPIM Survey: Uncovering Intolerance and Teacher Radicalism.," 2017), 94, Https://ppim.uinjkt.ac.id/category/2/post/survei-ppim2018:-menyibak-intoleransi- dan-radikalisme-guru.AccessedFebruary, 252019.

${ }^{76}$ Deliar Noer, Discussing National Figures (Bandung: Mizan, 2001), 90-92.

77 Chiara Formichi, Pan-Islam and Religious Nationalism: The Case of Kartosuwiryo and Negara Islam Indonesia. (Indonesia, 2010), 125-46. 
attitude towards the Dutch Colonial Government which no longer trusted the government. ${ }^{78}$

Other Indonesian literacy wars can be seen from the Ulama political movement. They were able to mobilize the war against Dutch colonialism. October 21, 1945, Kyai in all of Java and Madura held a meeting involving precarious in ANO's office Jl. Bubutan VI / 2. After going through an emergency meeting at night, on October 22, the Kyai declared jihad fi sabiilillah which came to be known as "Jihad Resolution". The Muslims welcomed the call with an uproar. Intended, the war broke out throughout East Java, specifically the City of Surabaya. That happened before because of attending Mujahids from various parts of the country. The impact of Jihad Resolution is commonly known as such, able to mobilize the most colossal Islamic war that has ever occurred in Indonesian history. This was then famous for the November 10, 1945 event. ${ }^{79}$ As stated by Said Aqill Siroj, published in Surabaya on October 22, 1945, KH Hasyim Ashari issued a fatwa on Jihad to defend Indonesia's independence against NICA-The Netherlands Indies Civil Administration. The content of Surabaya's liturgical war jihad is to defend the homeland. Its nature is Fardhu Ayyin or obligatory like prayer for everyone to defend the homeland. Whoever defends the homeland is martyred like defending religion. And whoever betrays his homeland and his country may be killed by his blood. At that time, Ashari did not say infidel. At that time, if Muslims became Japanese spies or Dutch spies could be killed. In Islamic jurisprudence it is called bughat. 80

Furthermore, Muhammad Natsir and the Masyumi party were important in Indonesian Islamic literacy. Natsir has become a symbol of heroism or the seeds of the struggle of Islamist movements in Indonesia. ${ }^{81}$ This began with his rebellion in the Sukarno era because of his persistence in emphasizing the role of Islam in the state over the nationality who also wanted to accentuate nationalism. Natsir became one of the nodes of conflict in terms of unrest in areas in Indonesia that were about to break away. For example the DI / TII Movement, the Andi Azis Movement, the APRA Movement, the Revolutionary Government of the Republic of Indonesia (PRRI), and the RMS Movement as Indonesian regional

78 Hiroko Horikoshi, The Dar ul-Islam Movement in West Java (1948-62): An Experience in the Historical Process. (Indonesia, 1975), 58-86.

${ }^{79}$ Gugun El-Guyanie, The Most Shar'ah Jihad Resolution (Yogyakarta: Pustaka Pesantren, 2010).

80 "Najwa's Notes with Said Aqil: Said Aqil Regarding Kafir (Part 2), in."

81 S. Soebardi, "Kartosuwiryo and the Darul Islam Rebellion in Indonesia" 14, no. 1 (1983): 109-33. 
separatism that threatens internal security. Natsir joined and joined PRRI (Poesponegoro, 1992).In the past, Masyumi was the only party defending regional interests. Natsir as an important figure there. 82 September 1950, Sukarno gave Natsir to form the Natsir Cabinet by Presidential Decree No. 9 of 1950. However, due to his failure, March 21, 1951 Sukarno finally dissolved Natsir's Cabinet.83 April 26, 1951, Natsir disagreed with Soekarno, whose nationalism was criticizing Islam as an ideology while praising the secularization of the Turkish Kemalism version. Natsir actually pouted secularization as a factor behind the destruction of the Ottomans. Natsir also criticized Soekarno for not paying attention to the welfare of the Indonesian region outside Java. ${ }^{84}$

Natsir can be seen as a representation of the Islamic elite in Indonesia's practical politics in the mid-1930s who loved the country in the name of Islam. That period, Indonesian democracy was constitutional. In general, the state constitution is formulated by Indonesia's new elite from civil society with a Western education background. They want the great role of Islam to constantly change with each characteristic but eventually break down. 85 Natsir is like the ulama and other Indonesian Islamic elites who believe more that the state is an important means to ensure that Islamic law applies in society, divine sovereignty over the state, Shari'a as a source of state law and the implementation of shura principles embodied in the Jakarta Charter; Saafroedin,; Elson.

Regional separatism in Indonesia is not in the context of demands for the formation of a new state or rebellion, but rather a protest about how the constitution is carried out evenly. 86 Separartism coincided with the condition of government in Indonesia still not stable after Dutch aggression. Another situation affecting separatism is the relationship

82 Taufik Abdullah, Moderator Introduction: The Constitutional Tragedy of Natsir Politics," in Lukman Hakiem (ed.), M. Natsir on the History Stage of the Republic. (Jakarta: Republika, 2008), 5-6.

83 P.N.H. Simanjuntak, Cabinet of the Republic of Indonesia: From the Beginning of Independence to the Reformation (Jakarta, 2003), 116=124.

${ }^{84}$ Rusli Kustiaman Iskandar, "Basic Polemic of Islamic State between Soekarno and Mohammad Natsir, 2 ed., vol. 19, 2003, 203-25; Audrey Kahin, "Natsir and Sukarno: Their Clash over Nationalism, Religion and Hui Yew-Foong (ed.), Encountering Islam: The Politics of Religious Identities in Southeast Asia. (Singapore: ISEAS Publishing, 2013), 191-217.

${ }^{85}$ Herbert Feith, The Decline of Constitutional Democracy in Indonesia (Jakarta and Kuala Lumpur: Equinox Publishing, 2007), 146.

${ }^{86}$ Lukman Hakiem (ed.), M. Natsir on the History Stage of the Republic (Jakarta: Penerbit Republika, 2008), 34. 
between the central government and the regions. This relationship creates various imbalances in development, especially in areas outside Java. The seeds of regional conflict arise over the development imbalances since the issuance of Regional Regulation No. 50 of 1950 concerning the establishment of an autonomous region by the Province of Central Sumatra. At that time, the area of West Sumatra and Riau Province at that time still covered the Riau Islands and Jambi now. ${ }^{87}$ Most experts believe that the demands for autonomy and the central role of Islam as the basis of the country were misinterpreted by Sukarno as a rebellion. As a result of misinterpretation, from 1962 to 1964, Natsir was arrested and imprisoned in Malang then July 26, 1966, during the New Order, he was released. ${ }^{88}$

In an effort to develop the Islamic political struggle, Natsir led the Masyumi Islamist political party. He firmly included Islam as an ideology. September 5, 1950, he was appointed as the fifth Indonesian Prime Minister. However, on April 26, 1951, he resigned from his position because of a disagreement with President Sukarno. As a result, he is increasingly vocal. In his speeches, he voiced the importance of the role of Islam in the country and Indonesian society as a whole. He believes Islam is inseparable from Indonesian culture. As a result Sukarno imprisoned Natsir ${ }^{89}$ In 1966, he was released but constantly criticized the Suharto government for making it back banned. To disseminate political ideas in the name of Islam, Natsir wrote extensively about the thoughts and movements of the Indonesian Islamists. ${ }^{90} \mathrm{He}$ is also active in Islamic organizations. From 1928 to 1932, he became the chairman of the Jong Islamieten Bond (JIB) Bandung, as the figure behind the missionary movement of the Islamic Unity organization ${ }^{91}$ that "studied" to Ahmad

87 Gusti Asnan, Rethinking Regionalism: West Sumatra in the 1950s (Jakarta: Yayasan Obor Indonesia, 2007).

88 Burhan Magenda, "Three Natsir Periods,"in Lukman Hakiem (ed.), M. Natsir on the History Stage of the Republic. (Jakarta: Penerbit Republika, 2008), 13.

89 Burhan Magenda, "Three Natsir Periods," in Lukman Hakiem (ed.), M. Natsir on the History Stage of the Republic.

90 Abdurrahman, "Jong Islamieten Bond 1925-1942 (History, Thought and Movement)." (1999), 97-104.

91 Thohir Luth, M. Natsir, Da'wah andThe Tought. (Jakarta: Gema Insani, 1999), 23-24; M. Taufik Rahman, "'Figures behind the Islamic Unity Da'wah Movement,' in Dadan Wildan Anas, et.all.Anatomy of the Islamic Union Da'wah Movement MOVEMENT"' (Sunan Gunung Jati State Islamic University, 2015), 23840, Bandung, Academic Draft. 
Hassan, who later became Persis.92 Even though he was educated in the Netherlands, Natsir was determined to fight the Dutch and his influence was still strong in Indonesia until the New Order era through education..

Resistance to colonialism is closely related to Natsir's vital position in the rise of Indonesian Islam, including the world. Natsir is involved in Islamic organizations, such as the Majelis Ta'sisi Rabitah Alam Islami, Majelis Ala al-Alami lil Masjid, meaning the World Council of Mosques based in Mecca, the Center for Oxford Islamic Studies in the UK, and the World Muslim League in Karachi, Pakistan. February 26, 1967 in Indonesia, he formed and became chairman of the Indonesian Islamic Da'wah Council Foundation (DDI). This is one of the Islamic organizations in Indonesia. He is also involved in Rabitah Alam Islami (RAI) or the Islamic World League, the largest non-governmental Islamic organization in the world. RAI was founded in Dzulhijah $1381 \mathrm{H}$ or May 1962 in Makkah, Saudi Arabia.

Natsir also founded the Campus Da'wah Institution (LDK), a campus student organization at each university in Indonesia, with Islam as its principle. All of that is an Islamic activism of contemporary campuses in Indonesia to communicate or as a connecting wire to the ideology of Middle Eastern Islamism to Indonesia. ${ }^{33}$ However, because of the expressions of the New Order regime, LDK has become a fertile field for radicalism ideological nursery not only HTI, LDK, and the Unity of Action for Indonesian Muslim Students (KAMMI) also become seedlings of radicalism. ${ }^{94}$ The nursery of radicalism ideology which has a root connection with LDK formed by Natsir, occurred in the late 1990s after Masyumi's figures were old and dead. As a result, the Islamic community lost an authoritative figure who could accommodate militant groups in the late 1990s. ${ }^{95}$ All the aspirations of the Indonesian Islamic movements that exist, especially the radicalism movement struggle to restore the seven

92 Siti Aisyah, "Ahmad Hassan Bandung's thoughts about Islamic Theology." (Tesos, Pogram Study Program for Islamic Thought Postgraduate Islamic University of North Sumatra Medan., 2007), 32-33; Howard M Federspiel, "Persatuan Islam: Islamic Reform in Twentieth Century Indonesia." (Ithaca: Cornell University Press, 1970), 13.

93 Claudia Nefn Saluz, "Dakwahkampus.com as Informal Student Web Portal of Hizbut Tahrir Indonesia," in Nadja-Christina Schneider, Bettina Graf (eds.), Social Dynamics, 2011, 67-84.

${ }^{94}$ Arbi Sumandoyo dan Azyumardi Azra, "Radicalism in Developing Campus Because There Is No Counter-Movement," 2019, https://tirto.id/radikalismedi-kampus-berkembang-karena-tak- ada-gerakan-tandingan-cPqQ.

95 Burhan Magenda, "Three Natsir Periods," in Lukman Hakiem (ed.), M. Natsir on the History Stage of the Republic., 14. 
popular words in the formulation of the Pancasila, the obligation to carry out Islamic law for adherents, in the state constitution. ${ }^{96}$ Don't stop there. The Islamic movements, as Bell said, also strive continuously to make Indonesia an Islamic state. One Islamic fighting spirit in the Jakarta Charter, known as the Medina Charter. The reason, Indonesia is the country with the largest Muslim population in the world (2011: 262-298).

\section{E. The War of Electronic Islamic Literacy by Ustad Virtual}

Modern Islamic literacy war is seen in radical Islamic movements. It strengthened in Indonesia, but the network was international and wide, until Afghanistan and Yemen were no longer Mecca as in the early Ulama. Interestingly, the text of the written DI/TII/NII proclamation and which was read by Kartosuwiryo became Islamic literacy as its main reference. That is, the DI/TII/NII proclamation experienced endless metamorphosis in Indonesia's radical Islamic movement. It appears in the following two pictures. ${ }^{97}$ With the proclamation literacy, a number of Islamists mobilized the Islamic political movement to carry out separatism for certain interests, especially in areas outside Java. These include the Free Aceh Movement (GAM) in Aceh, the Free Riau Movement in Riau, the South Maluku Republic (RMS) in Maluku, Darul Islam / Indonesian Islamic Army, the Indonesian Islamic State (DI/TII/NII) in West Java, the Command Movement Jihad in Central, Western, Jemaah Islamiyah (JI), a fusion of transnational Islamic movements in Southeast Asia covering Indonesia, Singapore, Brunei, Malaysia and the Philippines, and the New Indonesian Islamic State Regional Command 9 (NII Baru KW 9) which developed into Ma'had Al-Zaytun (MAZ) under the education concept of Al-Zaytun Islamic Boarding School in West Java. A number of these movements carried out bughat, rebellion against legitimate government.98 They mobilized Indonesian Muslims willing to 'istishhad', looking for martyrs for Islam ${ }^{99}$

96 Adnan Buyung Nasution, The Aspiration for Constitutional Government in Indonesia: A Socio-Legal Study of Indonesian Konstituante 1956-1959 (Jakarta: Pustaka Sinar Harapan, 1992), 358-60.

${ }_{97}$ Nugroho Dewanto (ed.), Daud Beureueh: Rebellious Freedom Fighters (Jakarta: KPG, 2018), 146-48.

98 Lukman Santoso Az, Complete History of the Islamic Separatist Movement.Yogyakarta: Penerbit PALAPA., 2014, 288-330.

99 David Cook, Martyrdom in Islam (New York: Cambridge University Press, 2007), 31; Jajang Jahroni, Defending the Majesty of Islam: Indonesia's Front Pembela Islam, 1998-2003. (Washington D.C: University of Washington Press, 2008), 15-30; 
Member of Darul Islam, Al Caidar saw Kartosuwiryo as a form of rebellion against Jakarta politicians who increasingly chose the direction of Indonesian politics towards communism. Kartosuwiryo's rebellion was also directed at Sukarno who was considered an infidel. So with this rebellion, he felt that he was continuing the struggle for Indonesian independence because Indonesia had surrendered to the Netherlands through the Renville Agreement in January 1948. Through this rebellion obliged every Muslim to carry out jihad fi sabilillah to reject every crime, injustice and uphold justice and legal truth Allah. For this reason they proclaimed NII. ${ }^{100}$ Therefore, it is important to pay attention to the understanding of the perpetrators.

According to Nasir Abas who had been a member of the Al Jamaah Al Islamiyyah, the separatism movement of Indonesian Islamic movements wanted to carry out the literal messages of Allah in the Qur'an which were interpreted by their Amirs such as Ustad Abdus Somad aka Ustad Abu, aka Ustad Abu Bakar Ba'asyir and Ustad Abdu; Halim alias Abdullah Sungkar or Hilmy Bakar Almascaty Chair of the Islamic Defenders Front Central Board. The aim is to maintain religion, the Islamic ummah and state that they believe to be subjective when they become combatants in Afghanistan. For example, in the Maluku Jihad war carried out by Laskar Jihad and commanded by Ja'far Umar Thalib, the warriors carried out the fatwa of the high priest of the Jihadist Salafis. They also mobilized the literacy of jihad from a number of Islamic media, namely Witnesses, Sabili, Ummi, Tarbawi, Radio As-Syafi'iyah, Annida, Eramuslim.com, Media Dakwah, Suara Hidayatullah, and Laskar Jihad Online as well as various bulletins or magazines in the Ahlus stream Sunnah Wal Jamaah like Salafy and AsSunnah to spread the message of Salafi. ${ }^{101}$ The Maluku Islamic War confirms the high level of interest and interest of the Hadrami clerics on a geo-political scale towards the dynamics of domestic politics in Indonesia by utilizing Islamic literacy in the form of a fatwa. ${ }^{102}$ Jihad fi sabilillah is believed by the perpetrators above which have been described in its development manifest in the war of Islam to the regions in Indonesia.

The current phenomenon of Indonesian Islamic radicalism seems to be increasingly blatant since the collapse of the New Order. According to

M. Ridlwan Nasir, "Live in Destiny as Martyr: The Venture of Front Pembela Islam (FPI) in Contemporary Indonesia" 02, no. 01 (2008): 217-21.

100 Holk H Dengel, Darul Islam and Kartosuwirjo: Steps to Embody Failures that

Fail. (Jakarta: Pustaka Sinar Harapan, 1995), 7-37.

101 Noorhadi Hasan, Laskar Jihad: Islam, Militancy, and the Search for Identity in

Post-New Order Indonesia Translated by Hairus Salim, 104-321.

102 Noorhadi Hasan, 73-92. 
Bruinnessen, Indonesian Islam is suspected of experiencing a conservatives turn. For example inter-religious conflict in several regions, acts of terror ahead of Christmas in the church, Bali bombings I and II terror, efforts to include the Jakarta Charter into the Constitution, the enactment of Shari'a Regional Regulations, internal conflicts between puritan camps and progressive camps in NU and Muhammadiyah, symptoms the conservatism of the Indonesian Ulema Council with the Fatwa of Ahmadiyya heresy and understanding of secularism, pluralism and liberalism, involvement in street demonstrations against pornography and porno-action, the strengthening of conservative Islamic networks across countries, especially through the education axis of the Middle East, the formation of the Islamic Sharia Preparation Committee, the emergence of efforts to revive the ideals of the establishment of the Islamic State of Indonesia, and the radical movement in Solo.

Recent research on the attitudes and behavior of conservatism, violence, extremism and radicalism among Indonesian Muslim millennials has increased. Ironically, the funnel of the spread of extremism and radicalism is precisely the chest of the virtual Ustad Indonesia. The literacy war mobilized by the Ustad caused Indonesian Muslim youth to be exposed to radicalism. It was documented in the results of research on 935 resource persons from Muslim Youth in High Schools and Universities with an Age range of 17-24 years in 18 Cities / Regencies in Indonesia conducted by the UIN Jakarta CSRC and PPIM Institute with CONVEY and UNDP during September 2017 to January 2018.103 One contributing factor is precisely because the strengthening of the role of Islamic literacy in more popular ways is electronic. That is, electronic Islam is being loved by the younger generation of Indonesian Muslims through electronic media-based social media networks, both online and offline. Popular Islamic literacy is filled by various main sources of impromptu virtual clerics. Called impromptu because the Ulema of the Ustadz has not been tested, be it the process of education or Islamic expertise but gained popularity by electronic media in cyberspace. This phenomenon emphasizes Islamic celebrity genre is more viral than conventional.

Conservatism, violence, extremism and Islamic radicalism have also increased among madrasa teachers, especially the private sector. Educators reduce religious learning in schooling institutions to more radical things.

103 Chaider S Bamualim, Hilman Latief, dan Irfan Abubakar, Millennial Muslim Youth Conservatism, Identity Hibridation, and Radicalism Challenges (Jakarta: Center for Religious and Cultural Studies at the Syarif Hidayatullah State Islamic University Jakarta, 2018), xi-xiv. 
That was seen in 2018 from the results of the Jakarta PPIM survey. In his research, PPIM focused on Islamic society. The survey was conducted in the span of time between 6 August to 6 September 2018. The study sample was taken from 34 provinces, regencies/cities in Indonesia randomly. With a target population of 2,237 Muslim teachers in schools/madrasas at the kindergarten/RA level, elementary/MI, junior high/MTs, high school/technical high school/MA. They are teachers of Language, Mathematics and Natural Sciences (MIPA), Sosial Sciences, Islamic Education and Character, Arts and Skills, Guidance and Counseling, Class Teachers, Principals. The Islamic view of the teacher refers to the aspect of how Islamic Shari'a is applied in all political domains, showing the style referred to as radical Islamism. The understanding of Islamic radicals emphasizes the importance of Shari'a as the main reference source in all aspects of life. ${ }^{104}$ The PPIM results were continued from the results of the LaKIP-Islamic and Peace Study Institute held in October 2010 to January 2011 against Islamic Education students and teachers in Jabodetabek. They show a surge in intolerance and radicalism in the scope of Indonesian schools.

It seems that the latest praxis of education in Indonesia is in the situation of openness and strengthening of democracy. But in such situations precisely the researchers found the actualization of the latent power of conservatism in Islamic movements in Indonesia. From a number of teachers and students studied, the early / early DI / TII / NII romanticism that had been born in a national history was emerging. The romanticism, although by strong Islamic groups in Indonesia, constantly raised banners to break it academically like the conclusions of Ainur Rofiq Al-Amin, but Indonesian Islam continued to be dragged into a period too far into the khilafah system. This romanticism was strengthened by the war on Islamic liturgy through the work of Taqi al-Din al-Nabhani namely Nizam al-Islam, al-Nizam al Iqtisadi fi al-Islam, Nizam al-Hukm fi al-Islam, al-Dustur, Muqaddimat al-Dustur, al-Dawlah al-Islamiyah, and alKhilafah, for example, which were continuously reproduced by Hizb utTahrir Indonesia (2017: 25-26, 279). Although another reality of the Indonesian Islamic movement shows another strategy. In certain situations, especially in the absence of strength or weakness, conservative groups of Islam can accept and be willing to live with other different groups, and are willing to recognize the government of a secular state or a state that is not

104 "PPIM Survey Reveals 3 Factors Related to Teacher Intolerance and Radicalism.," 2019, Https://conveyindonesia.com/survey-ppim-ungkap-3-faktoryang-terkait-intoleransi-dan- radikalisme-guru/. 
based on Islam. The reason is to wait for the situation or momentum and the right time to place Islam as the basis of the state or form an Islamic State. 105

\section{F. Conclusion}

The study from the beginning to the end of the previous shows Indonesian Islamism is far ahead of the phenomena that exist in other worlds, especially in the West, as has been echoed by Western researchers. One of the factors that gave birth to Indonesian Islamism is precisely the Islamic literacy that continues to evolve in various shades to the present. Basically, Islamism shows a subjective belief that Islam as a political movement is considered the only solution to any problem that exists in Indonesia. This belief has continued to evolve, at least being at the root of a number of existing violence even at the root of terrorism despite the incessant practice of democracy that is increasingly open and strengthening in Indonesia.

This paper finds new knowledge about the evolution of the Islamic literacy war in various media, forms and events produced by the Ulama. They are actually political scholars, Islamist elites and Ustad have been viral for certain political interests. The evolution of the Islamic literacy war was able to mobilize the religious milleniarism movement in Indonesia turned into an Islamic political Islam movement both conservatively and even radically. In that change there were many followers. They are even willing to die. If this is not handled persuasively, the separatist movement is still a real threat to the unity and integrity of the nation[.]

\section{REFERENCES}

A. Pieter E Korver. The Samin Movement and Millenarism, ijdragen tot de Taal-,Land-en Volkenkunde, Deel 132, 2/3de Afl, 249-266, 1976.

Abdul Majid. "Critical Study of Sabil al-Muhtadin's Hadiths." Thesis, Postgraduate School Syarif Hidayatullah State Islamic University Jakarta, 2007.

105 Abdul Munir Mulkan dan Bilveer Singh, Under Shadow Democracy Lead N11: Dilemma of Islamic Politics in Modern Civilization (Jakarta: Penerbit Buku Kompas, 2011), xi,298; Solahudin, The Roots of Terrorism in Indonesia: From Darul Islam to Jema'ah Islamiyah, Translated by Dave McRae. (Australia: UNSW Press, 2013), 74-98; Kumar Ramakrishna, Islamist Terrorism and Militancy in Indonesia: The Power of the Manichean Mindset (Singapore: Springer Sciences+Business Media, 2015), 211-20. 
Abdul Munir Mulkan, dan Bilveer Singh. Under Shadow Democracy Lead N-11: Dilemma of Islamic Politics in Modern Civilization. Jakarta: Penerbit Buku Kompas, 2011.

Abdurrahman. "Jong Islamieten Bond 1925-1942 (History, Thought and Movement)." 1999.

Abdurrahman ., dan Wahid. "Foreword", in Martin van Bruinessen, Yellow Book, Islamic Boarding School, and Tarekat: Islamic Traditions in Indonesia. Jakarta: Mizan, 1995.

Abigail Green, dan Vincent Viaene (eds). Religious Internationals in the Modern World: Globalization and Faith Communities Since 1750. New York: Palgrave Macmillan, 2012.

Abu Daudi. Maulana Sekh Moh. Arsyad al Banjari Pioneer of Islamic Da'wah in South Kalimantan,. Vol. 6. Mimbar Ulama, 1976.

Adnan Buyung Nasution. The Aspiration for Constitutional Government in Indonesia: A Socio-Legal Study of Indonesian Konstituante 19561959. Jakarta: Pustaka Sinar Harapan, 1992.

Ahmad Suriadi. Sheikh Muhammad Arsyad Al-Banjari in the Political Dynamics of the XIX Century Banjar Kingdom. Banjarmasin: Research Center and publishing LP2M Antasari State Islamic Institute, 2014.

Ahmed Ibrahim Abushouk, dan Hassan AhmedIbrahim. The Hadhrami Diaspora in Southeast Asia: Identity Maintenance Or Assimilation? Leiden: Brill, 2009.

A.K. Pringgodigdo. Movement History of the Indonesian People Tenth Printing. Jakarta: Dian Rakyat, 1984.

Amelz. H.O.S. Tjokroaminoto: His Life and Struggle. jakarta: Bulan Bintang, 1952.

Anthony Bubalo, Greg Fealy, dan Whit Mason. Zealos Democrats: Islamism and Democracy in Egypt, Indonesia and Turkey. New South Wales, Australia: Lowy Institute for International Policy, 2008.

Anthony Reid. An Indonesian Frontier: Acehnese and Other Histories of Sumatra. Singapore: NUS Publishing, 2005.

A.Pieter E. Korver. Sarekat Islam: Ratu Adil Movement? Jakarta: Grafitipers, 1985.

Arbi Sumandoyo, dan Azyumardi Azra. "Radicalism in Developing Campus Because There Is No Counter-Movement," 2019. https:/ / tirto.id/radikalisme-di-kampus-berkembang-karena- takada-gerakan-tandingan-cPqQ.

Arif Zulkifli, et.all (eds.). Agus Salim Joker Diplomat and the Pole of Republic. Jakarta: KPG. “2018 PPIM Survey: Uncovering Intolerance and

Teacher

Radicalism.,"

2017. 
Https://ppim.uinjkt.ac.id/category/2/post/survei-ppim-2018:menyibak-intoleransi- dan-radikalisme-guru.AccessedFebruary, 25 2019.

Audrey Kahin. "Natsir and Sukarno: Their Clash over Nationalism, Religion and Democracy, 1928-1958," in Hui Yew-Foong (ed.), Encountering Islam: The Politics of Religious Identities in Southeast Asia. Singapore: ISEAS Publishing, 2013.

Azyumardi Azra. "A Hadrami Religious Scholar in Indonesia: Sayyid Uthman," in Ulrike Freitag, William G. Clarence-Smith (eds.). Hadrami Traders, Scholars and Statesmen in the Indian Ocean, 1750s1960s. New York: Brill, 1997.

- - - "Hadhrami Scholars in the Malay-Indonesian Diaspora: A Preliminary Study of Sayyid Uthman" 2, no. 2 (1995): 1-33.

- - - . Middle East Ulama and Archipelago Islands Network Abda XVII \& XVII: $\quad$ Roots of Indonesian Islamic Renewal Third Printing. Jakarta: Kencana Prenada Media, 2007.

- - - . "Preface: The Dynamics of PSII The Political Prism of Indonesian Islam," inValina Singka Subekti. Indonesian Islamic Party. Jakarta: Yayasan Pustaka Obor Indonesia, 2014.

- - - . The Origins of Islamic Reformism in Southeast Asia: Networks of Malay- Indonesian and Middle Eastern "Ulama" in the Seventeenth and Eighteenth Centuries. New South Wales: Allen \& Unwin., 2004.

B Schrieke. Indonesian Sociological Studies II. Bandung: The Hague, 1957.

B.J Boland. The Struggle of Islam in Modern Indonesia. The Hague: Martinus Nijhoff, 1971.

Budi Setyraso dkk (eds.). Tjokroaminoto The Founding Teacher Sixth Printing. Jakarta: KPG, 2018.

Burhan Djabir Magenda. "Foreword,"in Valina Singka Subekti, Indonesian Islamic Sarikat Party: Political Contestation to Elite Power Conflict. Jakarta: Yayasan Pustaka Obor Indonesia, 2014.

Burhan Magenda. "Three Natsir Periods,"in Lukman Hakiem (ed.), M. Natsir on the History Stage of the Republic. Jakarta: Penerbit Republika, 2008.

C. Snouck Hurgronje. Muhammadanism: Lectures Regarding the Origins of the Development of Religion and Politics, and Their Current ConditionsTranslated by Ruslani. Yogyakarta: IRCSoD, 2019.

C. Van Dijk. Rebellion Under the Banner of Islam: The Darul Islam in Indonesia. The Hague: Martinus Nijhoff Publishers, 1981.

Chaider S Bamualim, Hilman Latief, dan Irfan Abubakar. Millennial Muslim Youth Conservatism, Identity Hibridation, and Radicalism 
Challenges. Jakarta: Center for Religious and Cultural Studies at the Syarif Hidayatullah State Islamic University Jakarta, 2018.

Chiara Formichi. Pan-Islam and Religious Nationalism: The Case of Kartosuwiryo and Negara Islam Indonesia. Indonesia, 2010.

Claudia Nefn Saluz. "Dakwahkampus.com as Informal Student Web Portal of Hizbut Tahrir Indonesia," in Nadja-Christina Schneider, Bettina Graf (eds.), Social

Dynamics, 2011.

Dale F Eickelman, dan James Piscatori. "Preface," inDale F. Eickelman, James Piscatori (eds.).Muslim Travellers. Pilgrimage, Migration, and the Religious Imagination. Berkeley,. Los Angeles: University of Califronia Press, 1990.

Dan Idwar Shaleh. Papper Trade and the Rulling Class of Banjarmasin in the Seventeenth Century. Leiden: Ducth-Indonesian Historical Conference., 1978.

Daniel S Lev. Islamic Courts in Indonesia: A Study in the Political Bases of Legal Institutions. Berkeley and Los Angeles, CA: University of California Press, 1972.

David Cook. Martyrdom in Islam. New York: Cambridge University Press, 2007.

Deliar Noer. Discussing National Figures. Bandung: Mizan, 2001.

Dzulkifli Hadi Imawan. The Intellectual Network of Shaykh Abdusshamad Al- Falimbani and His Contribution in Grounding Islam in Indonesian Archipelago at 18th Century AD, Millah: Jurnal Studi Agama, Vol. 18, No. 1, 31-50, 2018.

Ebrahim Ahomed Mahida 1993. History of Muslims in South Africa: A Chronology. Durban: Arabic Study Circle, Mahida.

Elia Tambunan. Islamism: One Plot from Egypt, Pakistan and Indonesia. Banten: Arashi Publisher, 2019.

Fauzi. Islamists vs. Secularists: Idiological Fighting in Indonesia. Semarang: Walisongo Press, 2009.

Gugun El-Guyanie. The Most Shar'ah Jihad Resolution. Yogyakarta: Pustaka Pesantren, 2010.

Gusti Asnan. Rethinking Regionalism: West Sumatra in the 1950s. Jakarta: Yayasan Obor Indonesia, 2007.

Hamka. My father: Curriculum vitae H. Abd Karim Amrullah and the Struggle of Religion in Sumatra. Jakarta: Djajamurni, 1967.

Hanafi. "Genealogy of the Study of Hadith of Ulema al-Banjari" 2, no. 2 (2017): 169-94.

Harry J Benda. "South East Asian Islam in the Twentieth Century," in M. Holt, Awn KS Lambron, Bernard Lewis (eds.). The Cambridge History of Islam. New York: Cambridge University Press, 1970. 
Harsono Tjokroaminoto. Following in the Footsteps of the Father's Struggle. Jakarta: Gunung Agung, 1985.

Hasan Muarif Ambary. Historical Dynamics and Socialization of Islam in Southeast Asia 11th-17th Century AD. Jakarta: Depdikbud (Indonesian Ministry of Education and Culture, 1997.

Herbert Feith. The Decline of Constitutional Democracy in Indonesia. Jakarta and Kuala Lumpur: Equinox Publishing, 2007.

Hiroko Horikoshi. The Dar ul-Islam Movement in West Java (1948-62): An Experience in the Historical Process. No. 20 vol. Indonesia, 1975.

Holk H Dengel. Darul Islam and Kartosuwirjo: Steps to Embody Failures that Fail. Jakarta: Pustaka Sinar Harapan, 1995.

Howard M Federspiel. "Persatuan Islam: Islamic Reform in Twentieth Century Indonesia." Ithaca: Cornell University Press, 1970.

Husaini Abbas Rahmadi2012. Islamic Banjar: Genealogy and Intellectual References in Historical Trajectories. Banjarmasin: The State Islamic Institute of Antasari Press, 2012.

Imdadun Rahmat. New Flow of Radical Islam: Transmission of Middle Eastern Islamic Revivalism to Indonesia. Jakarta: Erlangga, 2005.

Jajang Jahroni. Defending the Majesty of Islam: Indonesia's Front Pembela Islam, 1998-2003. Washington D.C: University of Washington Press, 2008.

Jajat Burhanudin. Ulemas and Power: Muslim Political Elite Struggles in Indonesian History. Bandung: Mizan, 2012.

Jamaluddin Al-Afghani, dan Muhammad Abduh. Ta'assubTranslated by Abdullah Basmih. Singapore: Ta'assub, 1950.

Jaqueline Aquino Siapno. Gender, Islam, Nationalism and the State in Aceh: The Paradox of Power, Co-Optation and Resistance. London: RoutledgeCurzon, 2002.

J.J. Ras. Hikayat Banjar: A Study in Malay Historiography. Martinus Nijhoff: The Hague, 1968.

Karl D Jackson. Traditional Authority, Islam, and Rebellion: A Study of Indonesian Political Behavior. Berkeley, Los Angeles: University of California Press, 1980.

Keat Gin Ooi (ed.). Southeast Asia: A Historical Encyclopedia, from Angkor Wat to East Timor. Santa Barbara, California: ABC Cilio, 2004.

Kerry Ward. Networks of Empire: Forced Migration in the Dutch East India Company. Cambridge, UK and New York: Cambridge University Press, 2009.

Khader Ahmad. "Autoriti Hadith in the Book of Sufism Writing Jawi: One Study of the Book of Hidayah al-Salikin." Journal of al-Qur'an \& Hadith Al-Bayan, 5, no. 10 (2007): 98-99. 
Kumar Ramakrishna. Islamist Terrorism and Militancy in Indonesia: The Power of the Manichean Mindset. Singapore: Springer Sciences+Business Media, 2015.

Lukman Hakiem (ed.). M. Natsir on the History Stage of the Republic. Jakarta: Penerbit Republika, 2008.

Lukman Santoso Az. Complete History of the Islamic Separatist Movement.Yogyakarta: Penerbit PALAPA., 2014.

M. Ridlwan Nasir. "Live in Destiny as Martyr: The Venture of Front Pembela Islam (FPI) in Contemporary Indonesia" 02, no. 01 (2008): 217-21.

M. Taufik Rahman. "'Figures behind the Islamic Unity Da'wah Movement,' in Dadan Wildan Anas, et.all.Anatomy of the Islamic Union Da'wah Movement MOVEMENT." Sunan Gunung Jati State Islamic University, 2015. Bandung. Academic Draft.

M. Zein Hassan. Indonesian Revolution Diplomacy Abroad. Jakarta: Bulan Bintang, 1980.

Mal An Abdullah. Shaykh Abdus-Samad al-Palimbani: Biography and Scientific Heritage. Yogyakarta: Pustaka Pesantren, 2015.

Mansoor Jaffer. "Guide to the Kramats of the Western Cape," 1996.

Mas'oed Abidin. "Minangkabau Encyclopedia.Minangkabau:" Minangkabau: Center for Islamic Studies, 2005.

MB. Hooker. Adat Law in Modern Indonesia. Oxford, UK: Oxford University Press,1978., 1973.

Merle Calvin Ricklefs. Mystic Synthesis in Java: A History of Islamization from the Fourteenth to the Early Nineteenth Centuries. EastBridge Books, t.t.

Michael Francis Laffan. Islamic Nationhood and Colonial Indonesia: The Umma Below the Winds. London and New York: Routledge, 2003.

Milner AC. "Islam and The Muslim State," dalam M.B. Hooker (ed.), Islam in South Easth Asia. Leiden: Brill, 1988.

Mujiburrahman. "Sufism in the Banjar Society: Continuity and Change in Religious Traditions," 2, no. 2 (2013): 153-83.

"Najwa's Notes with Said Aqil: Said Aqil Regarding Kafir (Part 2), in." Youtube, https://www.youtube.com/watch?v=RTiyIzt7ecA.AccessedMarch, 27 2019.

Neil J. Smelser. Theory of Collective Behavior. New York: Free Press, 1962.

Noorhadi Hasan. Laskar Jihad: Islam, Militancy, and the Search for Identity in Post-New Order Indonesia Translated by Hairus Salim. Jakarta: LP3ES associate with KITLV Jakarta, 2008. 
Noorhaidi Hasan. “Towards Popular Islamism," in Noorhaidi Hasan (ed.), Islamic Literature of Millennial Generation: Transition, Appropriation, and Contestation. Yogyakarta: Postgraduate of Sunan Kalijaga State Islamic University Yogyakarta, 2018.

Nugroho Dewanto (ed.). Daud Beureueh: Rebellious Freedom Fighters. Jakarta: KPG, 2018.

Onghokham. Sukarno: Left Man, Revolution \& G30S 1965. Jakarta: Komunitas Bambu, 2009.

Peter B.R. Carey. "The Cultural Ecology of Early Nineteenth Century Java: Pangeran Dipanagara." A Case Study. Occasional Paper. The Institute of Southeast Asian Studies, 1974.

- - - . The Power of Prophecy: Prince Dipanagara and the End of an Old Order in Java, 1785-1855. Leiden: KITLV Press, 2007.

Peter B.R.Carey. Destiny: The Life of Prince Diponegoro of Yogyakarta, 1785-1855. London: Peter Lang, 2014.

P.N.H. Simanjuntak. Cabinet of the Republic of Indonesia: From the Beginning of Independence to the Reformation. Jakarta, 2003.

"PPIM Survey Reveals 3 Factors Related to Teacher Intolerance and Radicalism.," 2019. Https://conveyindonesia.com/survey-ppimungkap-3-faktor-yang-terkait-intoleransi-dan- radikalisme-guru/.

R. William Liddle. New Order Elections: Tidal Political Power. Jakarta: LP3ES, 1995.

Radical Islam Rising: Muslim Extremism in the West. Vol. Quintan Wiktorowicz. Maryland: Rowman \& Littlefield Publishers, Inc, 2005.

Rahma Baniamt. "Political Gait Haji Agus Salim in Sarekat Islam (1915-1940 AD),." Thesis, Department of Islamic History and Culture Faculty of Adab and Cultural Sciences Sunan Kalijaga State Islamic University Yogyakarta, 2017.

R.E.Elson. The Idea of Indonesia: A History. Cambridge, UK: Cambridge University Press, 2008.

Robert F Berkhofer Jr. A Behavior Approach to Historical Analysis. New York: Free Press, 1969.

Robert Van Niel. The Emergence of the Modern Indonesian Elite. Bandung: W. Van Hoeve, 1960.

Rusli Kustiaman Iskandar. "Basic Polemic of Islamic State between Soekarno and Mohammad Natsir,. 2 ed. Vol. 19, 2003.

S. Soebardi. "Kartosuwiryo and the Darul Islam Rebellion in Indonesia" 14, no. 1 (1983): 109-33.

S Yunanto. Militant Islamic Movements in Indonesia and South-East Asia. Jakarta and Singapore: Friedrich-Ebert-Stiftung, 2003. 
Samsul Munir Amin. Percik the Thought of the Kiai. Yogyakarta: Pustaka Pesantren, 2009.

Sartono Kartodirdjo. Protest Movements in Rural Java: A Study of Agrarian

Unrest in the Nineteenth and Early Twentieth Centuries. New York: Oxford University Press, 1973.

- - - . The Peasants' Revolt of Banten in 1888: Its Conditions, Course and Sequel: A Case Study of Social Movements in Indonesia. echt. Netherlands: Springer Science+Business Media Dordr, 1966.

Shagir Abdullah. Syekh Muh. Arsyad alBanjari, The Islamic Sun. Pontianak: al Fathanah, 1983.

Siti Aisyah. "Ahmad Hassan Bandung's thoughts about Islamic Theology." Tesos, Pogram Study Program for Islamic Thought Postgraduate Islamic University of North Sumatra Medan., 2007.

Solahudin. The Roots of Terrorism in Indonesia: From Darul Islam to Jema'ah Islamiyah, Translated by Dave McRae. Australia: UNSW Press, 2013.

Suradi. Haji Agus Salim and Political Conflict in Sarekat Islam. Jakarta: Pustaka Sinar Harapan, 1997.

Syekh Muhammmad Arsyad Zamzam, dan Jusuf Halidi. ..Kalimantan Great Ulama: Sech Muhammad Arsyad al-Banjari. Martapura: Yayasan al-Banjari, 1968.

Syukur, M. Asywadie (ed.). 2003. Sheikh Muhammad Arsyad al-Banjari: Kitab Sabil al-Muhtadin. Surabaya: Bina Ilmu, t.t.

Takashi Shiraishi. An Age in Motion: Popular Radicalism in Java, 19121926. Itacha: Cornell University Press, 1990.

Tamar Djaja. Sjech M. Arsyad al Banjari in the Indonesian Library. Djakarta: Bulan Bintang, 1965.

Taufik Abdullah. Moderator Introduction: The Constitutional Tragedy of Natsir Politics," in Lukman Hakiem (ed.), M. Natsir on the History Stage of the Republic. Jakarta: Republika, 2008.

Taufik Adnan Amal, dan Samsu Rizal Panggabean. Politics of Islamic Law: from Indonesia to Nigeria. Jakarta: Pustaka Alvabeta, 2004.

The Old Soerabaia Volume 1. Surabaya: Surabaya Tourism Departement, 2002.

Theodore G.Th Pigeud, dan Hj. de Graff. Islamic States in Java 1500-1700. Lieden \&Bandung: The Haque, 1976.

Thohir Luth. M. Natsir, Da'wah andThe Tought. Jakarta: Gema Insani, 1999.

TIim Kell. The Roots of Acehnese Rebellion, 1989-1992. Itacha: Cornell SEAP Publication, 1995. 
Wan Mohd Shagir Abdullah. Sheikh Muhammad Arsyad al-Banjari Author Sabil al- Muhtadin. Kuala Lumpur: Khazanah Fathaniyah, 1990.

William Cummings. A Chain of Kings: The Makassarese Chronicles of Gowa and Talloq. Leiden: KITLV Press, 2007.

Yusliani Noor. "The History of the Development of Islam in Banjarmasin and the Role of the Banjar Sultanate (XV-XIX Century)" 11, no. 2 (2012): 239-53.

Yusuf Da Costa. Pages from Cape Muslim History. Pietermaritzburg, South Africa: Shuter \& Shooter, 1994. 
| AKADEMIKA, Vol. 24, No. 01 January - June 2019 